\title{
Military Traditions of the Don Cossacks in the Late Imperial Period
}

\author{
T.E. Zulfugarzade, A. Yu. Peretyatko
}

For citation: Zulfugarzade T.E., Peretyatko A. Yu. Military Traditions of the Don Cossacks in the Late Imperial Period. Vestnik of Saint Petersburg University. History, 2020, vol.65, issue 3, pp. 771-789. https://doi.org/10.21638/11701/spbu02.2020.305

The issue of the development of military traditions in the Cossack milieu on the eve of the $20^{\text {th }}$ century is a matter of debate in contemporary Russian historiography. A number of scholars (e. g., A. V. Iarovoi and N. V. Ryzhkova) have argued that the Cossacks' system of historical military traditions remained viable until 1917. Other researchers (e.g., O. V. Matveev) have claimed that the system of Cossack military traditions had actually experienced a crisis and collapsed by then. This paper seeks to establish the truth. To accomplish this, the authors draws upon a set of newly discovered responses from Russian generals to the report of the Maslakovets Commission. The paper shows that the Cossacks' historical traditions of military training in the stanitsas were forgotten not by the beginning of the $20^{\text {th }}$ century, but by the 1860 s. During this time, declining combat capability of the Don units, with $50 \%$ of the young Cossacks entering military service by the beginning of the $20^{\text {th }}$ century "poorly" and "unsatisfactorily" prepared, drew the attention of Alexander II. The War Ministry endeavored to revive the Cossacks' martial games and military training in the stanitsas. However, according to certain Cossack generals, its actions, at the same time, had violated the historical Cossack traditions of military training, causing, by certain testimonies, their total ruin by the beginning of the $20^{\text {th }}$ century. The main conclusion drawn in this paper is that the image of the Cossack as a "dashing equestrian warrior" going back to official pre-revolutionary historiography is highly idealized.

Keywords: Don Cossacks, military traditions, martial games, preparation for service, idealization of the past.

Teimur E.Zul'fugarzade - PhD in Law, Associate Professor, Plekhanov Russian University of Economics, 36, Stremiannyi per., Moscow, 117997, Russian Federation; teymurz@yandex.ru

Теймур Эльдарович Зульфугарзаде - канд. юрид. наук, доц., Российский экономический университет им. Г.В.Плеханова, Российская Федерация, 117997, Москва, Стремянный пер., 36; teymurz@yandex.ru

Artyom Yu. Peretyatko - PhD in History, Joint Laboratory of the International Network Center for Fundamental and Applied Research and Volgograd State University; 100, pr. Universitetsky, Volgograd, 400062, Russian Federation; 1150, Connecticut Av., Washington, District of Columbia, USA, 20036; ArtPeretatko@yandex.ru

Артем Юрьевич Перетятько - канд. ист. наук, совместная лаборатория Международного сетевого центра фундаментальных и прикладных исследований и Волгоградского государственного университета, Российская Федерация, 400062, Волгоград, пр. Университетский, 100; США, 20036, округ Колумбия, Вашингтон, Коннектикут авеню, 1150; ArtPeretatko@yandex.ru

(c) Санкт-Петербургский государственный университет, 2020 


\section{Военные традиции донского казачества в позднеимперский период}

\section{Т. Э. Зульфугарзаде, А. Ю. Перетятько}

Для цитирования: Zulfugarzade T.E., Peretyatko A. Yu. Military Traditions of the Don Cossacks in the Late Imperial Period // Вестник Санкт-Петербургского университета. История. 2020. Т. 65. Вып. 3. С.771-789. https://doi.org/10.21638/11701/spbu02.2020.305

Вопрос о развитии военных традиций в казачьей среде накануне XX в. в современной российской историографии остается дискуссионным. Ряд авторов (например, А. В. Яровой, Н. В. Рыжкова) доказывают, что исторические военные традиции казачества оставались жизнеспособными до 1917 г. Другие авторы (в частности, О.В. Матвеев), напротив, утверждают, что к этому времени военные традиции казачества переживали кризис и разрушались. Авторы статьи пытаются установить истину на основании публикаций современников и архивных источников из Российского государственного военно-исторического архива, Отдела рукописей Российской национальной библиотеки и Государственного архива Ростовской области. Ряд материалов, в первую очередь отзывы российских генералов на доклад комиссии Н.А. Маслаковца, изучавшей все стороны быта донских казаков в 1899 г., прежде не вовлекались в исторический оборот. В статье показано, что традиции военного обучения казаков в донских станицах были забыты не к началу XX в., но к 1860-м гг. В это время падение боеспособности донских частей обратило на себя внимание Александра II, а к началу XX в. уже 50 \% молодых казаков выходили на службу «слабо» и «неудовлетворительно» подготовленными. Военное Министерство пыталось возродить военные игры и военное обучение в станицах, однако на практике вместо возрождения произошло конструирование принципиально новых элементов казачьего повседневного быта. Более того, по мнению ряда генералов, в ходе этого конструирования были нарушены исторические казачьи традиции военной подготовки, что, по некоторым свидетельствам, к началу XX в. вообще привело к уничтожению многих настоящих казачьих военных традиций и их замене искусственным и неэффективным конструктом. Важнейшим выводом из статьи является то, что образ казака как «лихого конного воина», восходящий к дореволюционной официальной историографии, сильно идеализирован.

Ключевые слова: донское казачество, военные традиции, военные игры, подготовка к службе, идеализация прошлого.

\section{Introduction}

The Don Cossacks' military traditions... their famed "cavalry charge", their unrivaled art of horseback riding, their personal courage - these have been an object of admiration among numerous military figures and writers, both Cossacks and Europeans. In 1870, N.I. Krasnov, a high-level official at the Main Administration of Cossack Forces, stated with satisfaction: "The view of the Cossacks' particular value in serving in cavalry has been voiced in works by top foreign cavalry writers, like Nolan, de Brack, and Azemar. It has been shared by our celebrated guerilla warriors of 1812, 1813, and 1814" . Nearly a half century earlier, in 1831, one of the first Don historians I. S. Ul'yanov noted that many Poles were hindered by their hatred of the Cossacks, their opponents, from acknowledging the outstanding military qualities of members of the Don forces. However, participants of the 1830-1831 Polish uprising who "had taken part in some real business, rather

\footnotetext{
${ }^{1}$ Krasnov N.I. Voennoe obozrenie Zemli Voiska Donskogo. St. Petersburg, 1870. P.X.
} 
than boisterous, unrestrained merrymaking, are now rendering all justice to the Cossacks' superior military skills" ${ }^{\text {. }}$. As early as the beginning of the $20^{\text {th }}$ century, the government was promoting the idea of the necessity to preserve the Cossacks' military traditions. To this end, they even introduced martial games for children in the stanitsas to help facilitate their "military development" 3 . In this context, one could encounter statements like the following in the state media: "What we have now is a mighty and powerful Quiet Don, its glorious regiments being the jewel of the Russian cavalry. We, the sons and daughters of the Don, must only stick to the wonderful examples left to us by our grandfathers and fathers and try to follow in their footsteps"4.

It is no wonder that today, a century after the demise of the Russian Empire's Cossack troops in the civil war, even professional historians tend to find the image of their military traditions, the "wonderful examples" followed by the Cossacks, overly idealized. Even N. V. Ryzhkova, the author of the only monograph on the Don Cossacks' participation in the Russo-Japanese War and World War I, has stated the following to this effect: "In the early $20^{\text {th }}$ century, the Cossacks were characterized by a special state of mind and psyche and a predisposition for military service, which had become their second nature. For instance, a prominent Cossack history researcher E. P. Savel'ev noted 'The Cossacks' military virtues are as distinctive as those of the entire Russian people - yet, their inherent capacity for warfare, perhaps an innate gift for it, only multiplies and stimulates their brilliance further. Among ordinary Cossacks one could often encounter individuals with a knightly spirit, who were filled with a sense of honor'". No other variety of the Russian armed forces was as viable as the Cossacks ${ }^{5}$. However, in substantiating the above tenets, the researcher invokes not archive sources but official publications of the Russian Empire, more specifically a book entitled "The Pictures of the Past of the Quiet Don", which was published at the directive of Don ataman A.V.Samsonov ${ }^{6}$. What are we then to say of texts by contemporary Cossacks inclined to idealize their traditions and perceive them uncritically, relying not only on pre-revolutionary state media publications but blatantly unscholarly materials of the early $20^{\text {th }}$ century written by amateur historians? ${ }^{7}$

Contemporary Russian historiography offers an entirely different view of the Cossacks' military traditions - specifically, that these traditions, shaped by the distinctive conditions of feudal and frontier societies, by the beginning of the $20^{\text {th }}$ century had been receding into the past and had been kept afloat artificially. It is a view relying on personal research by Cossack military figures and scholars of the past. A well-known Kuban historian O. V. Matveev notes that " $20^{\text {th }}$ century publications by officers were filled with concern about the decline of the military principle in the Cossack environment and a zeal for preserving Cossack culture. $\langle\ldots\rangle$ The decline in the Cossacks' morale and military efficiency was associated with a weakening of their former patriarchal relations in the stanitsa, a decline in military discipline, an excessive inflow of people from other areas

${ }^{2}$ Ul'ianov I. S. Zapiski I. S. Ul'ianova // Sbornik Oblastnogo voiska Donskogo statisticheskogo komiteta. Vol. III. Novocherskassk, 1902. P. 69.

${ }^{3}$ Matveev O. V. Iz istoricheskogo i voenno-kul'turnogo naslediia kazachestva Kubani. Krasnodar, 2011. P. 237.

${ }^{4}$ Krasnov P. N. Kartiny bylogo Tikhogo Dona. St. Petersburg, 1909. P. 520.

${ }^{5}$ Ryzhkova N. V. Donskoe kazachestvo v voinakh nachala XX veka. Moscow, 2008. P.2-5.

6 Ibid.

${ }^{7}$ Kashkarov A.P. Kazaki: traditsii, obychai, kul'tura (kratkoe rukovodstvo nastoiashchego kazaka). Rostov-on-Don, 2015. 
into the Kuban region, and the 'natural consequence of the absence of an enemy for the Cossacks to face" "8. However, a definitive answer as to the actual state of the Cossacks' military traditions on the eve of the $20^{\text {th }}$ century can only be obtained if we try to separate facts from myths - by drawing upon relevant archive documents that provide insight into the traditions of a certain Cossack host, as well as documents intended not for the ordinary reader and designed to promote certain ideas in society, but those intended for internal use by the War Ministry. The question is only whether there existed documents that captured the state of the Cossacks' system of military traditions and whether Russian military functionaries engaged at all in the study thereof as part of their everyday work, as opposed to their writing para-governmental works carrying a certain ideological message.

\section{Materials and methods}

In the late $19^{\text {th }}$ century, Don public figures often complained in the press that military service had become too hard for the Cossacks, while the War Ministry's efforts to preserve in the stanitsas their military traditions had produced an opposite effect, cultivating a hatred for the very idea of Cossack service. For instance, a prominent Don public figure V. Ya. Biryukov argued that the region's military system had turned into a "nightmare that now haunts the Cossacks all their life" . As a consequence, members of the last elective body in the Don region, the Don Gentry Assembly, resolved to appeal to the Emperor personally to notify him of the fact that the "the deplorable economic situation of the Cossack population of the Don Cossack Host Province grows worse with every passing year" and that the time was near when "the Don Host will be unable to fulfill the duties and obligations placed upon it" 10 . This would result in the establishment of a special commission headed by Lieutenant General N. A. Maslakovets, which would issue a detailed report on the causes behind the decline in the well-being of the Don Cossacks ${ }^{11}$. Of interest, however, is not so much the report itself, which is known pretty well to historians, but a set of newly discovered responses to it written by battle commanders from the military regions and corps of the Russian army in which Cossack units served. These responses were systematized by the War Ministry in 1900, and are now stored in the Russian State Military and Historical Archive $^{12}$. Many Russian generals, especially those of Cossack descent, dwelt in detail on the causes behind the decline of the system of Don military traditions, which in their view, had reached a dangerous scale.

It is worth adding to this array of documents a set of memoranda, reports, and records of the War Ministry that can confirm or disprove various statements on Cossack

${ }^{8}$ Matveev O. V. Iz istoricheskogo i voenno-kul'turnogo naslediia kazachestva Kubani. P. 237.

9 Biriukov V.Ia. Doklad chlena Komissii V. Ia. Biriukova o vliianii voinskoi sluzhby donskikh kazakov na ikh khoziaistvennyi byt. Novocherkassk, 1899. P. 12-13.

${ }_{10}$ Materialy Vysochaishe utverzhdennoi komissii dlia issledovaniia prichin, podryvaiushchikh khoziaistvennyi byt voiska Donskogo, i dlia izyskaniia mer k vosstanovleniiu ego ekonomicheskogo blagosostoianiia // Gosudarstvennyi arkhiv Rostovskoi oblasti (GARO). F.410. Op. 1. D. 682. L. 3.

11 Maslakovets N.A. O zaniatiiakh vysochaishe uchrezhdennoi 16-go iiunia 1898 goda Komissii v oblasti voiska Donskogo i o dostignutykh eiu rezul'tatakh: Doklad sostoiashchego v rasporiazhenii voennogo ministra General'nogo shtaba general-leitenanta Maslakovtsa 23 avg. 1899 g. St. Petersburg, 1899.

12 Svod zakliuchenii stroevykh nachal'nikov po trudam komissii generala Maslakovtsa i po voprosu o issledovanii prichin, podryvaiushchikh khoziaistvennyi byt donskogo kazach'ego naseleniia, i izyskaniia sposobov k vosstanovleniiu ekonomicheskogo blagosostoianiia Voiska Donskogo // Rossiiskii gosudarstvennyi voenno-istoricheskii arkhiv (RGVIA). F. 330. Op. 61. D.2109. 
traditions encountered in state media publications or those by officers. On their basis, it could be possible to gain an insight into what the Don Cossacks' proverbial system of military traditions was like in the $19^{\text {th }}$ century and to establish which of them were really still in existence and which had already died out.

Much of the archive material used herein is being introduced into scholarly discourse for the first time. In general, many sources on the history of the Cossacks of the second half of the $19^{\text {th }}$ - early $20^{\text {th }}$ centuries, even published, are only now beginning to be studied (this applies even to such a group of sources as descriptions of travelers ${ }^{13}$ ). For this reason, this work is making an extensive use of the historical-descriptive method which involves the use of direct quotes. While the historical-comparative method was employed to compare the various sources, the historical-systemic method was used to examine the Don Cossacks' military traditions as a single entity.

\section{Discussion}

Theoretically, the Cossacks' key military traditions included habituation to military service in early childhood and militarization of their morals and manners, which, in particular, was reflected in the way they brought up their children and adolescents, as well as their penchant for staging in the stanitsas all kinds of martial games known as shermitsias. Here is what is stated to this effect by A. V. Iarovoi, a researcher with a particular interest in the history of martial games in the Don region: "This [the Cossacks' martial games] has been written about by all researchers and travelers who have come into contact with the Cossacks since the $18^{\text {th }}$ century. For instance, J. Potocki provides a colorful description of Cossack wrestling, and A.I. Rigelman describes the Cossacks' equestrian contests in Monastyrskoe Urochishche at Shrovetide. Similar descriptions of an ethnographic nature are provided by V.D. Sukhorukov, E. N. Katel'nikov, I.I. Krasnov, V. M. Pudavov, S. F. Nomikosov, M.N. Kharuzin, P.N. Krasnov, and others. <..> The Cossack system of military drills remained in place up until the beginning of the $20^{\text {th }}$ century" ${ }^{14}$. As can be seen, the number of authors who have mentioned the Don Cossacks' martial games is more than extensive. Truly, details make all the difference. The very same A. V. Iarovoi mentions Don general and writer I.S. Ul'yanov, who in the 1830 s wrote that "shermitsias have become a thing of the past in the Don region"15. Rather than going into facts from the lives of prominent Don military figures and local history experts of the $19^{\text {th }}$ century, it will be worth examining what they actually wrote about the Cossacks' military training - this will help assess the degree to which this training retained its value in the post-Napoleon era.

Let us start with I.S. Ul'yanov, whose personal archive is part of the State Archive of Rostov Oblast (GARO). In his manuscripts of the 1830s, he wrote about martial games and military training in the stanitsas not as something that was becoming outdated but as "a pastime of ancient Don Cossacks" ${ }^{6}$. Whilst about the Don Cossacks' daily life that was

${ }^{13}$ Mininkov N.A., Mininkova L.V. The Cossack Region of Russia in the Characteristics of Russian Travelers of the Modern Era // Bylye Gody. 2019. Vol. 54, iss. 4. P. 1762.

${ }^{14}$ Iarovoi A. V. Traditsionnye voinskie igry donskikh kazakov v kontekste sokhraneniia istoricheskoi pamiati // Voina i voinskie traditsii v kul'turakh narodov Iuga Rossii. VII Tokarevskie chteniia. Rostov-naDonu, 2018. P. 14-22.

15 Ibid. P. 17.

${ }^{16}$ Literaturnyi material // GARO. F.243. Op. 1. D.28. L. 33 ob. 
contemporary to him he wrote the following: "Nowadays, after returning from service, the Cossack, first and foremost, engages in taking care of his family - he gets to remedy any disruptions and shortcomings in the life of the family, which are inevitable because of his absence, often a long one. If he gets distracted, he is no longer on top of things. You know what farmers say: 'one good day of work will feed you for an entire month in winter"'17. Ul'yanov's archive provides no testimony as to his personal observations of shermitsias, so none of this is described by him in detail. To prove the existence of the Cossacks' martial games, I.S. Ul'yanov cites the works of V.D. Sukhorukov describing the early history of the Don Cossacks, from which it follows that the actual fact of their existence by the 1830s is not very obvious ${ }^{18}$. With regard to this, it was characteristic of I. S. Ulyanov to idealize the military past of the Cossacks, and he was one of the founders of patriotic military propaganda on the Don ${ }^{19}$.

To substantiate the existence of military education and martial games in the Cossack milieu in the mid- $19^{\text {th }}$ century, historians often cite a book by the Cossack general I. I. Krasnov, a participant in the Crimean and Caucasian Wars, entitled "On Don Cossack Service", in which he writes the following: "It was natural for veteran warriors to tell stories about the military experiences of their own and the feats of other celebrated Cossacks; passionate young Cossacks, in turn, were excited to listen to those stories. Having listened to all sorts of stories about military life, the young people would mount their horses and ride out of the stanitsa to a place where they would try to act out what they had heard in the stories - which involved their splitting into two sides to reenact a battle. <...> Young Cossacks, in turn, served as a model for Cossack kids. Warfare was central to their infantile games, with them abiding by a set of rules similar to a military organization and having their superiors too. $<\ldots>$ Thus, it may be stated that military concepts were infused into the Cossack with the mother's milk" ${ }^{20}$. However, here too the author is writing about an uncertain period in the past, which is not linked with any particular events in the Don region. By contrast, the general approached the Cossacks' military traditions of his contemporary period, i. e. the 1850s, in an entirely different manner: "By the natural order of things, the Cossack, busy with his salutary rural labors, to which he devoted himself most diligently, was now no longer in a position to keep his military skills sharp and to enhance them with as much zeal as before" 21 .

What is more, I.I. Krasnov devoted to the training of the Don Cossacks an entire article entitled "The Training of Young Cossacks in the Don Host" 22 . This publication offers a lot more information on the condition of the system of military traditions in the Don region in the mid- $19^{\text {th }}$ century, and that information shatters the illusions of contemporary authors that the Cossack system of military traditions was prospering, and that the Cossack units of the Russian army were "perfectly reliable"23. "In the Don field regiments,

17 Literaturnyi material. L. $32 \mathrm{ob}$.

18 Ibid. L. 33 ob.

19 Peretyatko A. Yu.: 1) "Look, the British and the French": a Little about the Don Literary Propaganda during the Crimean War // Propaganda in the World and Local Conflicts. 2018. No. 5 (2). P. 39-48; 2) At the Origins of Don Military Propaganda: the Creative Activity of I. S. Ul'yanov at the Time of the Crimean War // Propaganda in the World and Local Conflicts. 2019. No. 6 (1). P. 8-18.

20 Krasnov I. I. O donskoi kazach'ei sluzhbe. St. Petersburg, 1852. P. 23-24.

21 Ibid. P. 35.

22 I. K. Obuchenie molodykh kazakov v Donskom voiske // Voennyi sbornik. 1865. No. 1. P.73-89.

23 Ryzhkova N. V. Donskoe kazachestvo v voinakh nachala XX veka. P.4-7. 
the Cossacks became acquainted with their duties and acquired all appropriate knowledge in military matters through their military service. Prior to this, their military training and development depended somehow only on home martial games, which, according to elders, existed back in the day in the stanitsas on a large scale - but this system of martial games began to go into decline at the beginning of this century and then disappeared altogether. You don't hear anything about it nowadays" ${ }^{24}$. Thus, I. I. Krasnov, likewise, did not witness shermitsias personally but only heard about them from "elders", so the descriptions of Cossack martial games in his book "On Don Cossack Service", which have not been cited herein intentionally, can by no means be regarded as credible. In fact, "A Military Review of the Land of the Don Host", released by the General Staff in 1864, stated the following, citing the very same I. I. Krasnov: "Subsequent to the glorious wars fought at the outset of this century and, most importantly, with the Don borders being secure now from attacks by enemy neighbors, the Cossacks have somehow settled down - and lost their fighting spirit. $\langle\ldots\rangle$ With all the Cossack's innate capabilities, he receives no military training before he enters military service" 25 . It should be noted that I. I. Krasnov in his other works opposed the idea of "isolation" of the Cossacks and advocated admitting combative representatives of other classes into the Cossacks. He argued that it was the only way to preserve the military effectiveness of the Don Cossacks ${ }^{26}$.

The internal documentation of the War Ministry, indeed, confirms the fact of the nearly total demise of the system of military training and martial games in the Cossack stanitsas in the $19^{\text {th }}$ century. In 1899, Commander of the Fifth Army Corps General of the Cavalry K. K. Bodisko wrote the following in relation to the training of young Cossacks: "The times have passed when incessant wars with neighboring nations and the need to protect the borders from nomad incursions helped the Cossacks to learn the art of war through real practice, that is via training that, clearly, is more substantial than theory-based abstract learning. This military practice, facilitated by particular historical conditions, helped fill the gaps in military education - which, as a side note, was not very hard in the beginning. With the cessation of continuous wars and achievement of tranquility along the borders, the Cossacks' natural talent for war began to fade. However, military traditions were still alive in Cossackdom, in the person of its older representatives. $\langle\ldots\rangle$ Yet, with the passage of time, many of the elders have died taking with them their military precepts and observations, much of which now belongs to the domain of folklore"27.

The gradual dying out of military training in the stanitsas, obviously, could not help but have a toll on the Cossacks' military qualities. In this context, of interest are the views of contemporary historians A. V.Zakharevich and K. V.Skiba, who, based on the Caucasian War experience, believe that the combat efficiency of the Don units declined sharply during the $1820 \mathrm{~s}$, attributing this specifically to a crisis in the Don system of military traditions ${ }^{28}$. N. I. Krasnov was of the view that the negative consequences of the "Cossacks not being exposed to any military training" were felt most acutely during the Crimean

${ }^{24}$ I. K. Obuchenie molodykh kazakov v Donskom voiske. P.73.

${ }^{25}$ Krasnov N. I. Voennoe obozrenie Zemli Voiska Donskogo. P. 228-229.

26 Volvenko A. A. Ivan Krasnov about "the Cossack nationality" and "the Don patriotism" (Based on Periodicals of the 1860s) // Russkaia Starina. 2016. Vol. 17, iss. 1. P. 34-38.

27 Svod zakliuchenii stroevykh nachal'nikov... L. 51-51 ob.

28 Zakharevich A.V., Skiba K.V. O donskikh kazakakh, sluzhivshikh na Kubanskoi linii v 17901830-ykh gg. // Rossiiskaia gosudarstvennost'v sud'bakh narodov Kavkaza — IX. Piatigorsk, 2016. P. 95. 
War ${ }^{29}$. Finally, I.I. Krasnov himself reminisced that the Don authorities became aware of the decline of the system of military traditions in the stanitsas only during the Polish uprising of 1863 , when it was found out that the "Cossacks, especially young ones, did not know how to shoot and had hard time using a rifle. $\langle\ldots\rangle$ In certain regiments, there are even some Cossacks who are poor at horseback riding" 30 . No matter which of these datings may be correct, by the mid-1860s the demise of the traditional system of military training in the Don stanitsas had become a fait accompli - consequently, it was even not the War Ministry but Alexander II that between 1863 and 1864 issued a directive about the need to "hurry up with adopting appropriate measures on the training of young Cossacks" 31 .

While the view that in the second half of the $19^{\text {th }}$ century many Don Cossacks did not know how to shoot and some were poor at horseback riding runs counter to the conventional image of the Cossack, it is substantiated by responses from a number of battle commanders to N. A. Maslakovets's report. For instance, Commander of the Seventh Army Corps P. G.Dukmasov, a Don Cossack by descent, stated with bitterness and indignation that the Seventh Don Cossack Regiment alone received in 189926 men who not just were poor horseback riders but seemed to have "never ridden a horse before" 32 . The general not only complained about the decline of the system of military traditions in the stanitsas but argued that this decline had reached that critical point when proper pre-combat training, where it was provided, turned from something useful into something harmful as it only "spoiled the material", with battle commanders having to retrain the young Cossacks in the forces now ${ }^{33}$. The general also wrote with an undisguised irony about his experience going back to the Russo-Turkish War of 1877-1878, when he had met a lot of Don "field-officers who were unable to ride a horse simply due to their phenomenal corpulence or because of a bad hernia", as well as field-officers who, instead of "going out there and charging in front of a company in an assault", could only "feed their horses with forage and maintain records on that" ${ }^{\prime 34}$.

Yet, P. G. Dukmasov may have dramatized it a bit. In fact, Commander of the Second Composite Cossack Division Kuban Cossack A. I. Domontovich maintained, by contrast, that the problem with horseback riding among the newly drafted Cossacks was associated with not so much the decline of the system of military traditions in the stanitsas but the false notion that the Cossack was supposed to enter service being a good military horseback rider. In his view, the newly drafted should have been expected to only "sit firm in the saddle", whilst they could learn the rest in the combatant forces, with the only reservation that the "high caliber of trick riding" should be maintained where it was still in place.

As can be seen, A.I. Domontovich too was of the view that it had become impossible in the stanitsas by the start of the $20^{\text {th }}$ century to nurture a full-fledged Cossack warrior although he did argue that it was too early to speak of the total decline of the system of military training in the Cossack hosts. Quite possibly, his more than optimistic estimation of the condition of the Cossack system of military traditions, compared with P. G. Duk-

${ }^{29}$ Krasnov N. I. Voennoe obozrenie Zemli Voiska Donskogo. P.XIV.

${ }^{30}$ I. K. Obuchenie molodykh kazakov v Donskom voiske. P. 79.

31 Ibid. P.79.

32 Svod zakliuchenii stroevykh nachal'nikov... L. 38.

${ }^{33}$ Ibid. L. 38 ob.

${ }^{34}$ Ibid. L. 38. 
masov's view, had to do with his Kuban, not Don, descent. The thing is that in the Kuban region military, in particular equestrian, traditions were dying out more slowly. The very same I. I. Krasnov wrote in the mid-1860s that the linear Cossacks started to "school a horse early on in childhood" so as to be able to enter service on a good familiar battle horse, whereas the Don Cossacks "acquired a horse mainly only when they were getting ready for actual service, that is when they no longer had time not only for habituating it for riding without reins but sometimes for getting it accustomed for the actual reins altogether" 35 . This pretty much explains the inability of some Don Cossacks to properly ride a horse - in the native stanitsas, even if they did train in horseback riding, they did not do so on battle horses. On the other hand, the above testimonies by contemporaries clearly reveal differences between the military traditions of the nation's different hosts, which may suggest that those could be explored separately.

Having ascertained that starting in the 1860 s, officers had been writing about a decline in the Cossacks' military skills caused by the downfall of the system of military training in the stanitsas in order to comprehend the scale of the problem faced by the Don host specifically, it is time now to switch from private estimations to reports from the War Ministry. These reports provide assessments of a set of key skills in randomly picked draftees in the Don regiments (see: Table).

Table. The War Ministry's Assessment of the Military Skills of Men Newly Conscripted into the Don Regiments

\begin{tabular}{|c|c|c|c|c|}
\hline Skill area & 1896 & 1897 & 1898 & 1899 \\
\hline Formation & $\begin{array}{l}\text { Poor }-4 \\
\text { Satisfactory - } 14 \\
\text { Good }-6\end{array}$ & $\begin{array}{l}\text { Poor }-1 \\
\text { Satisfactory }-18 \\
\text { Good }-6\end{array}$ & $\begin{array}{c}\text { Poor }-1 \\
\text { Satisfactory }-23 \\
\text { Good }-1\end{array}$ & $\begin{array}{c}\text { Poor }-4 \\
\text { Satisfactory }-15 \\
\text { Good }-2\end{array}$ \\
\hline Skill at arms & $\begin{array}{l}\text { Unsatisfactory }-3 \\
\text { Poor }-11 \\
\text { Satisfactory }-8 \\
\text { Good }-5\end{array}$ & $\begin{array}{l}\text { Unsatisfactory }-3 \\
\text { Poor }-7 \\
\text { Satisfactory }-12 \\
\text { Good }-6\end{array}$ & $\begin{array}{l}\text { Unsatisfactory }-1 \\
\text { Poor }-9 \\
\text { Satisfactory }-17 \\
\text { Good }-1\end{array}$ & $\begin{array}{l}\text { Unsatisfactory }-5 \\
\text { Poor }-4 \\
\text { Satisfactory }-12 \\
\text { Good }-1\end{array}$ \\
\hline $\begin{array}{l}\text { Horseback } \\
\quad \text { riding }\end{array}$ & $\begin{array}{l}\text { Unsatisfactory }-2 \\
\text { Poor }-5 \\
\text { Satisfactory }-12 \\
\text { Good }-8\end{array}$ & $\begin{array}{l}\text { Unsatisfactory }-8 \\
\text { Poor }-10 \\
\text { Satisfactory }-13 \\
\text { Good }-5\end{array}$ & $\begin{array}{l}\text { Unsatisfactory }-5 \\
\text { Poor }-1 \\
\text { Satisfactory }-22 \\
\text { Good }-0\end{array}$ & $\begin{array}{l}\text { Unsatisfactory }-7 \\
\text { Poor }-5 \\
\text { Satisfactory }-6 \\
\text { Good }-4\end{array}$ \\
\hline $\begin{array}{l}\text { Knowledge } \\
\text { of the Field } \\
\text { Manual }\end{array}$ & $\begin{array}{l}\text { Unsatisfactory }-3 \\
\text { Poor }-10 \\
\text { Satisfactory }-12 \\
\text { Good }-2\end{array}$ & $\begin{array}{l}\text { Unsatisfactory }-4 \\
\text { Poor }-5 \\
\text { Satisfactory - } 16 \\
\text { Good }-3\end{array}$ & $\begin{array}{l}\text { Unsatisfactory }-3 \\
\text { Poor }-4 \\
\text { Satisfactory - } 20 \\
\text { Good }-1\end{array}$ & $\begin{array}{l}\text { Unsatisfactory }-2 \\
\text { Poor }-4 \\
\text { Satisfactory - } 12 \\
\text { Good }-4\end{array}$ \\
\hline
\end{tabular}

Note. Data from Commission for the Study of the Needs of the Cossack Population of the Don Region $^{36}$.

A. I. Ul'yanov, an officer in the Military Staff of the Don Host, who first collected this information for N.A. Maslakovets, stated with sadness that half of the Cossacks entered

${ }^{35}$ I. K. Obuchenie molodykh kazakov v Donskom voiske. P. 82.

${ }^{36}$ Protokoly Komissii po issledovaniiu nuzhd kazachégo naseleniia Donskoi oblasti. [S.1.,] 1899. P.7-8. 
the regiments "unsatisfactorily or poorly prepared" 37 . Although in certain years the situation was a bit better, in 1896, as evidenced from Table 1, over $50 \%$ of the Cossacks failed their tests in knowledge of the field manual and skill at arms, while in 1897 and $189950 \%$ and up failed their horseback riding test. It was only in 1898 that more than half of the Cossacks managed to do well in the tests, although many still struggled with horseback riding, with none of the draftees getting a "Good" mark. And that is considering that these were trainees educated by a system of military training that had been in place for several decades now, running in alignment with directives from above, which will be discussed in detail further below. Consequently, in the 1860s the situation may have been even worse, with military training via martial games in the stanitsas having, indeed, been forgotten, as was suggested by I. S. Ul'yanov and I. I. Krasnov.

Therefore, the martial games and drills observed by researchers in the Cossack stanitsas later on bear only an indirect relation to the Cossacks' historical traditions. They were a reaction to the afore-mentioned directive of Alexander II, enjoining the authorities to "hurry up with adopting appropriate measures on the training of young Cossacks". Judging by I.I. Krasnov's testimony, the news of the Emperor's discontent with the caliber of the Don regiments had a bombshell effect in the Don region striking the entire Cossack population "like a thunder bolt" 38 . However, it didn't boil down to some form of "state patriotism amongst the Don Cossacks". Here is what the general had to say with regard to the local elite's logic: "If the Don Cossacks, who have become the first among all Cossack hosts in terms of rights, will not justify it by their merits, they may end up losing those rights" 39 . In the early 1860s, the entire Land of the Don Host was filled with rumors that the government was about to make inroads upon the Cossacks' privileges, with the events described by an eyewitness A. A. Karasev as follows: "In the stanitsas, much hubbub was raised over the mere rumor of an upcoming transformation - the turning of Cossacks into 'muzhiks' [common rural dwellers]" 40 . The War Ministry's central apparatus, indeed, performed calculations to determine whether the demilitarization of the Don Host would be profitable for the state treasury ${ }^{41}$. Although things never got to the point of specific steps being taken in the direction of annulling Don Cossackdom, the deep concern of members of the Don elite about the very possibility of losing the Don Host due to the regiments' declining military capacity was logical and justified. To this was added patriotism - but Don, not Russian, patriotism, with still-alive eyewitnesses of the 1812 war "unable to comprehend how their children and grandchildren ended up yielding precedence to those Lineitsy, of whom no-one had even heard in the glorious year 1812"42.

The Don authorities began to introduce military training in the stanitsas from above, under the control of local military officials. According to I. I. Krasnov, while initially this system of training, just like the martial games associated with it, was largely of an improvised nature, it, nonetheless, was popular with the Cossacks. "In certain districts, except Sundays and high days, they have dedicated to training a significant amount of their time, conducting it even during Maslenitsa and Bright Week; by the start of spring this year

37 Protokoly Komissii po issledovaniiu nuzhd kazach'ego naseleniia Donskoi oblasti. P.7.

38 I. K. Obuchenie molodykh kazakov v Donskom voiske. P. 84.

39 Ibid. P. 83.

${ }^{40}$ Karasev A. A. Bunt na Donu v 1862-1863 godakh // Istoricheskii vestnik. 1900. No. 80. P. 169.

${ }^{41}$ O sobranii kapitanom general'nogo shtaba Krasnovym svedenii otnositel'no stoimosti kazach'ikh voisk sravnitel'no s reguliarnymi // RGVIA. F.330. Op. 10. D.290. L. 115-158.

${ }^{42}$ I. K. Obuchenie molodykh kazakov v Donskom voiske. P. 84. 
a major portion of the Cossacks, and even many of their kids, have already learnt how to ride a horse and shoot" 43 . These achievements provided hope for the better. In 1871 , Military Minister D. A. Milyutin described his impressions of the young Don Cossacks as follows: "I was pleasantly surprised when, instead of a bunch of clumsy youths with zero experience on a horse, which I had expected, I saw brilliant equestrians who not only had gone through regiment training but galloped past me virtually performing some trick riding, at which they were no worse than the famed 'linear' Kuban and Terek Cossacks. In fact, I have drawn the conclusion that recently adopted measures regarding the training of young Cossacks have produced tangible outcomes, helping maintain in the Don Cossacks a military bearing, keep their riding skills sharp, and keep them perky" ${ }^{4}$. Of interest is the fact that initially the Minister, a Caucasian War veteran, had expected to see not excellent equestrians but "a bunch of clumsy youths". That being said, it can be seen that, thanks to the first successes of the new system of training, he was not deceived in his expectations.

However, in essence, it looked like the attempts undertaken between the 1860s and 1870 s to make the Don Cossacks' military training "natural" again, i.e. stemming from the characteristics of their daily life, not from government regulation, had failed. Among those who disagreed was a prominent Don statistician S. F. Nomikosov, who wrote the following: "The Don region's combative inhabitants have in place games that, likewise, are combative in nature. At Easter or Maslenitsa, their youth get together and arrange mock battles, with one side being the Cossacks and the other the Turks. There is the trick riding activity, in which the Cossacks show off their martial skills; they shoot from their rifles and perform all kinds of military evolutions. The battle concludes with a feast, in which older individuals take part as well" ${ }^{25}$. However, the writings of S. F. Nomikosov, secretary of the Don Statistics Committee, form part of the body of state media publications that, as was noted above, typically idealized the Don Cossacks' military qualities. The book from which this quote was taken, "Statistical Description of the Province of the Don Cossack Host", was published by none other than the Don provincial administration ${ }^{46}$. Nonetheless, S. F. Nomikosov wrote quite scantly of the Cossacks' martial games, without providing any local names or any details. This, certainly, does not signify that the Don statistician openly lied and the Cossacks did not stage martial games at Easter and Maslenitsa. However, what is not clear from his words is how common these games were across the province and whether they were of an improvised nature or were organized from above, by the military authorities. Meanwhile, in the early $20^{\text {th }}$ century, starting in 1910 , based on a directive from the War Ministry, it was mandatory to conduct military maneuvers in the stanitsas, engaging even children in them ${ }^{47}$. Could the local Don authorities have conducted similar maneuvers on their own initiative several decades prior to that?

In fact, M.N. Kharuzin, the author of the first study on the ethnography of the Don Cossacks, appears to have hardly witnessed in the 1880 s any martial games in the stanitsas. While there is an entire section in his study devoted to Cossack public holidays, like Easter and Maslenitsa, his descriptions differ significantly from those offered by S. F. Nomikosov. Here is how the ethnographer describes the celebration of Easter in one of the

\footnotetext{
${ }^{43}$ Ibid. P. 85.

44 Volvenko A. A. D. A. Milyutin and Cossacks // Bylye Gody. 2016. Vol. 40, iss. 2. P. 406.

${ }^{45}$ Nomikosov S. F. Statisticheskoe opisanie Oblasti Voiska Donskogo. Novocherkassk, 1884. P. 317.

46 Ibid.

${ }^{47}$ Matveev O. V. Iz istoricheskogo i voenno-kul'turnogo naslediia kazachestva Kubani. P. 237.
} 
Don stanitsas (Malodelskaya): "First, the Cossacks break their fast in their homes. Next, an attendant ['esaulets'] calls out special words ['zaklichka'], and everyone comes out to the public square with snacks in their hands. Then, an ataman comes out of the administrative building ['stanichnaya izba'] to congratulate all stanitsa residents on the holiday and treats them to vodka" 48 . It is alcohol, not martial games, that the Cossacks were focused on at Maslenitsa too. During this holiday, young Cossacks would "walk with the flag", a tradition that had very little of the military left in it - they would take a flag from the stanitsa ataman and walk from one homestead to another, "partying" ${ }^{2}$. M.N. Kharuzin's descriptions of Cossack festivals, which are a lot more detailed than those provided by S. F. Nomikosov, contain local dialect words used during them and appear to be more credible. M.N. Kharuzin mentions just two types of Cossack festive games related to military activity: horseracing and fist fighting. However, his accounts do not describe anything specifically military either - there is no division into the "Cossacks and Turks": "During this period, they typically stage horse races. The ataman rides to the hill, which at this time is full of curious stanitsa residents. Here, one of the sub-officers arranges the horses in their places and then commands: 'one, two, three - go!' The winner is granted a three-week furlough from his service, the second place finisher - a two-week furlough, and the third place finisher - a one-week furlough" ${ }^{50}$. Even less related to the Cossacks' traditional martial games, there were "wall-on-wall" fist fights, in which "alongside the Cossacks, part was also taken by individuals originally from other places living in the stanitsas and hamlets" 51 .

Having consulted the War Ministry's internal documentation helps have confirmation that in this debate the winner is M. N. Kharuzin, not S. F. Nomikosov. In studying the system of preparation of young Cossacks for service, the Maslakovets Commission devoted no attention to their martial games, as something unessential, focusing instead only on official training which was conducted by special instructors ${ }^{52}$. Martial games could no longer have major significance due to lack of material-technical support in the stanitsas. As mentioned earlier, in the 1860s I.I.Krasnov wrote that the Don Cossacks "acquired a horse mainly only when they were getting ready for actual service"53. All attempts to change this had failed, with members of the Maslakovets Commission even providing reasons as to why the Cossack getting a horse at the beginning of his training, two years before entering active service, was quite inconvenient: "A war horse, which might be four to seven years old at the time the Cossack was entering active service, should be acquired at the age of two, which would be quite inconvenient - both in terms of the choice of one and keeping it for the next two years, which was the case with those of modest fortune; or, those who acquired a horse that was older ran the risk of no longer having it at the time of standing in the first two combat-service lines" 54 . That being said, this lack of battle horses significantly reduced the value of horse races organized by the military authorities - most of them were won not by the best equestrians but by residents of rich stanitsas who had

${ }^{48}$ Kharuzin M.N. Svedeniia o kazatskikh obshchinakh na Donu: materialy dlia obychnogo prava. Iss. 1. M., 1885. P. 380.

49 Ibid. P. 378

${ }^{50}$ Ibid. P. 385.

51 Ibid. P. 386.

52 Protokoly Komissii po issledovaniiu nuzhd kazach'ego naseleniia Donskoi oblasti. P. 8-10.

${ }^{53}$ I. K. Obuchenie molodykh kazakov v Donskom voiske. P. 82.

${ }^{54}$ Protokoly Komissii po issledovaniiu nuzhd kazach'ego naseleniia Donskoi oblasti. P. 8. 
better horses when they began their official training ${ }^{55}$. The situation was even worse with equipment: at the start of their training program the Cossacks typically acquired only swords, lances, sword belts, fur-lined jackets, caps, and overcoats, whilst the rest, including saddles, was old, which was all right as long as it could get them through their fall and winter training sessions and their May camp (there were no rifles at all, as will be seen further below $)^{56}$. Eventually, not only traditional martial games did not have any special effect on the training of young Cossacks but almost all of this training in the stanitsas was pointless: "Based on the accounts of individuals who are competent in this, like district atamans and combat officers, during their winter training sessions in the stanitsas young Cossacks get to acquire only the scantiest of knowledge, most of which they end up easily forgetting, as is the case when they attend their May camp assemblies" ${ }^{\prime 2}$.

In this regard, of particular interest are the observations of P.G.Dukmasov, A. I. Domontovich, and N. A. Maslakovets, who believed that at some point there occurred a clash between the Cossacks' natural system of military traditions and the system of government regulation of military training in the stanitsas. It is worth noting here that while there still were certain forms of independent Cossack training in place in the 1860s, most contemporaries refused, as was shown above, to view them as a full-featured system of preparation for military service and real martial games. For instance, N. I. Krasnov, who recognized the truth of I. I. Krasnov's words that the Don Cossacks received no military training before they entered military service ${ }^{58}$, at the same time tells when describing everyday life in the stanitsas that "during Maslenitsa the Cossacks come together on horseback from across the area, elect officials from among themselves, arrange all sorts of contests, and practice their shooting at a sheet from horseback" 59 . In the view of the three generals mentioned above, the War Ministry should have focused not on regulating the Cossacks' preparation for service, hoping that the Don region would, as in past centuries, produce for the regiments full-fledged warriors, but on giving support to the local military traditions which were still in place, so that the active forces received not prepared warriors per se but, rather, good material to build on.

For instance, A.I.Domontovich notes that "the elements of the home training of young Cossacks, aimed at helping them grasp the fundamentals of service and gain the knowledge necessary for a serviceman, are so delicate that interpreting them, even in an active regiment, is quite a tall order for well-versed officers, not to mention instructor sub-officers" 60 . Consequently, he was against any attempts to institute proper training for Cossacks in the stanitsas suggesting that the funds expended on that be instead directed toward "rewarding the winners of horse races and trick riding contests during festivals in the stanitsas" and toward the operation of "voluntary shooting societies"61. The Kuban general's conclusion was as follows: "This kind of private, non-statutory, training that is

${ }^{55}$ Ibid. P. 6.

56 Ibid. P. 6.

57 Ibid. P.9.

${ }^{58}$ Krasnov N. I. Voennoe obozrenie Zemli Voiska Donskogo. P. 229.

59 Krasnov N. I. Materialy dlia geografii i statistiki Rossii, sobrannye ofitserami General'nogo shtaba. Zemlia voiska Donskogo. St. Petersburg, 1863. P. 424.

${ }^{60}$ Svod zakliuchenii stroevykh nachal'nikov... L. 64.

61 Ibid. L. 64 . 
not forced upon and is more exciting to them is what could form the basis of their preliminary training" 62 .

P. G. Dukmasov, who overall agrees with A.I. Domontovich, went even further trying to prove that not only Don sub-officers but many Don officers, some of whom were described as characterized by "phenomenal corpulence" or having "a bad hernia", as was noted above, could no way have provided instruction to young Cossacks. "Within the host, those in charge of training assemblies and their assistants for the most part assigned to this (still forming and developing) area by accident, were simply in no position to devote to it, with real benefit for the military training of Cossacks, much of their precious time, which they needed to take care of their household plots; these individuals were selected and supervised by the Military Staff and atamans of the departments, in which there served persons who, except for singular exceptions, were totally unversed in how to assess the level of officer preparedness both for field cavalry and frontline service" 63 . The Don general, too, argued that, first and foremost, it was necessary to focus on preserving military traditions in the actual stanitsas, adding to this that regulating the rules of service in the preparatory grade not only did not contribute to sustaining those traditions but actually was ruining them: "Having the Cossacks strictly follow a shooting manual and arming them with government-issue rifles, stored in warehouses, will stifle their own system of free-flowing training sessions and mounted-shooting contests, which they formerly conducted every year during Maslenitsa, as an ineluctable and essential pastime that brings together the old and the young and officers and ordinary Cossacks" 64 . And, whereas A. I. Domontovich limited himself to local conclusions about the ineffectiveness of the preparatory grade for young Cossacks, P. G. Dukmasov went further suggesting that the decline of the Don Cossacks' system of military traditions and their impoverishment had resulted within their milieu in "a direction of thought that has nothing in common with old Cossacks' concept of the Cossack's high and honorable standing. Formerly, in going through the hardships of service, the Cossack regarded service, with all its disastrous implications for his family, as a sacred duty to the Tsar, the Motherland, and the ancestors, but now they are beginning to look at it as a burden which they must flee and escape to the 'Yermakian land' or even Priamursky Krai"65.

While N.A. Maslakovets's reasonings with conerning the decline of the system of military traditions in the Don stanitsas may not be regarded as perfectly credible in certain respects, they are quite revealing. The thing is that N. A. Maslakovets was not a Cossack by descent, so his account of the way the Cossacks conducted military training in the $19^{\text {th }}$ century, which contradicts the observations of a contemporary, hardly deserves credence. That being said, of interest is the fact that he views the level of military skill displayed by the Cossacks in the 1860 s, criticized so sharply by contemporaries, as an unattainable ideal now, for the military training system had been damaged by excessive regulation and poor decision-making on the part of the authorities. Here is how N. A. Maslakovets describes how the training of young Cossacks was conducted earlier, before 1835, without specifying the source: "On reaching the age of one, a Cossack infant would be seated by his father or another veteran family member on a bareback (or harnessed) horse that was tak-

\footnotetext{
62 Svod zakliuchenii stroevykh nachal'nikov...L. 64.

${ }^{63}$ Ibid. L. 37 ob.

${ }^{64}$ Ibid. L. 38-38 ob.

${ }^{65}$ Ibid. L. 38 ob.
} 
en to water, which was like a special way to initiate a future Cossack warrior. Subsequently, military training for young Cossack children in the stanitsas was provided either through special learning sessions in the schools or as part of various folk games and horseracing tournaments held on public holidays or days-off, with senior Cossacks fondly keeping watch over the development in their youth of a spirit of adventurousness, valor, and dexterity in the handling of a horse and overcoming of all sorts of obstacles when hunting with a rifle, either afoot or horseback, fishing, or playing all kinds of games, like Taking of the Snow Town, chasing, swimming, etc." ${ }^{\prime 6}$. The special focus on this is needed, as publications like these help explain the failure of many historians to see that the Cossacks' military traditions began to die out no later than the start of the $19^{\text {th }}$ century: later authors often idealized Cossacksdom's past, viewing their time's problems as something new and not typical of former years. Consequently, state media authors, like S. F. Nomikosov and P. N. Krasnov, did not lie but substituted the wish for the reality, relying on materials similar to the afore-cited passage (N. A. Maslakovets arrived in the Don region in the 1860s, so he could not have witnessed the military training of Cossacks in the first half of the $19^{\text {th }}$ century), which cannot qualify as legitimate sources and are simply intended to idealize Cossackdom's past. Essentially, this kind of idealization was quite typical in the early $20^{\text {th }}$ century. For instance, Don public figure V. Ya. Biryukov described the $19^{\text {th }}$ century Don region as follows: "Each male soul, inclusive of children, had access to thirty desiatinas of land (the Cossacks themselves did not even know how much land there was per soul); the soil was fresh and fat and yielded bounteous harvests, twenty- and thirtyfold yields; this fertile land provided rich pastures and hayfields, which made it possible to have, apart from working cattle and horses, lots of idle livestock as well. Even in the medium-income household environment there were 60-100 heads of horned cattle and hundreds of sheep, and just about any family had a number of horses" ${ }^{\prime \prime}$. It is certain that the Don region did not have twentyfold crop yields in the early $19^{\text {th }}$ century ${ }^{68}$. Given that, later accounts of martial games being held among the Cossacks regularly during that time look unreliable against the backdrop of the accounts by I. S. Ul'yanov and I. I. Krasnov.

N. A. Maslakovets arrived in the Don area in 1864, which was right after Alexander II issued a directive about the need to "hurry up with adopting appropriate measures on the training of young Cossacks" 69 . Judging by the documentation produced by him, he did really witness the Cossacks' enthusiasm, described by I. I. Krasnov, with regard to carrying out the Emperor's directives - although, unaware of the actual directive, he must have thought the Cossacks' drills and games in the stanitsas to exclusively be a continuation of their historical traditions. To this effect he noted the following, particularly underscoring the role of the very stanitsas in the provision of training, which was still done in quite an improvised manner: "It is since the 50s and 60s that more or less definite requirements had been gradually set for the system of preparation of young Cossacks for future active

${ }^{66}$ Maslakovets N. A. Dokladnaia zapiska v Glavnoe upravlenie kazach'ikh voisk po povodu zamechanii voiskovogo atamana Voiska Donskogo na otchetnyi doklad N. A. Maslakovtsa o rezul'tatakh raboty Komissii dlia izyskaniia mer k vosstavnovleniiu ekonomicheskogo blagosostoianiia donskogo kazachestva // Otdel rukopisei Rossiiskoi natsional'noi biblioteki. F. 1055. D. 22. L. 4 ob.-5.

67 Biriukov V. Ia. Doklad chlena Komissii V. Ia. Biriukova o vliianii voinskoi sluzhby donskikh kazakov na ikh khoziaistvennyi byt. P. 1.

68 Sukhorukov V.D. Statisticheskoe opisanie Zemli Donskikh kazakov, sostavlennoe v 18221832 godakh. Novocherkassk, 1891. P. 188-189.

69 Spisok generalam po starshinstvu. Sostavlen po 1 maia 1901 goda. St. Petersburg, 1901. P. 226. 
service, although, owing to participation in this from the stanitsa societies, the old system of military training remained in place as well"70. Viewing it as a point of no-return, the general saw the War Ministry's critical error in the full transfer of control over the training of Cossacks in the stanitsas to the local military authorities, which took place in 1875: "In the new system of military training, young Cossacks in the middle- and older-age sections of the preparatory grade were totally removed from the influence of the stanitsa societies and subordinated to the military administrative authorities in the host, i. e., military districts, military commissioners, officers, and instructors from among stanitsa sub-officers. With the introduction of this measure, the interest of the stanitsas in the military preparation of young Cossacks for future service was totally lost, and a system which used to be perfectly alive in the Cossack milieu - when the young generation of Cossacks received their first lessons and guidance from battle-seasoned veterans and members of their own families who fondly kept close watch over the gradual development and admired the valor of their trainees - passed into the hands of the appointed authority"71. Concluding one of his publications, the general, who had served in the Don area for many years, exclaims: "It was not wise to encroach upon the foundations of specifically those Cossack traditions which up to 1875 were quite strong and effective in terms of maintaining the old Cossack spirit of fathers and grandfathers in young Cossack generations. <...> My nearly 30 years' experience in serving in the administrations of three Cossack hosts has sufficiently convinced me of the truth that only taking the former path - maintaining harmony between the interests of the stanitsa and those dealing with the preparation of young Cossacks for service in the combatant forces - will ensure the achievement of quite satisfactory results"72.

Given what was said above, the Maslakovets Commission's proposal to abolish centralized military education in the stanitsas, based on the state of affairs before the 1860s, appears to be quite understandable ${ }^{73}$. As an alternative, members of the Commission suggested calling the Cossacks up for active service not in December but in February, as had been done before, so that draftees could undergo training in the regiments now ${ }^{74}$. Out of the two dozen members of the Commission, only one - member of the Provincial Zemstvo Committee A.S. Ezhov - resolutely protested against the proposal arguing that this would result in "young Cossacks in the stanitsas no longer receiving training in horseback riding, the use of arms, and other military exercises", which had "formed an indispensable part of life in the Don stanitsas from remote times"75. That being said, he, too, acknowledged that "perhaps, the current system of preparatory education for the Cossacks is not meeting its purpose". However, he regarded as absolutely unacceptable from a historical viewpoint the idea of "abolishing the military training of young Cossacks in the stanitsas"76. Essentially, statements like these only proved that A.S.Ezhov's opponents were right - for it followed from his words that by the 1890s the system of military training

${ }^{70}$ Maslakovets N. A. Dokladnaia zapiska v Glavnoe upravlenie kazach'ikh voisk po povodu zamechanii voiskovogo atamana Voiska Donskogo na otchetnyi doklad N. A. Maslakovtsa o rezul'tatakh raboty Komissii dlia izyskaniia mer k vosstavnovleniiu ekonomicheskogo blagosostoianiia donskogo kazachestva. L. 5.

${ }^{71}$ Ibid. L. 5-5 ob.

72 Ibid. L. 6 ob.

${ }_{73}$ Protokoly Komissii po issledovaniiu nuzhd kazachego naseleniia Donskoi oblasti. P. 10-11.

${ }^{74}$ Ibid. P. 11.

75 Ibid. P. 11.

76 Ibid. P. 11. 
for Cossacks in the stanitsas remained in place only through government initiative, and that abolishing the preparatory grade would put an end to military training altogether. Nonetheless, the issue of what to do with the training of Cossacks next produced a rift among the Russian army battle commanders as well. For instance, P.G. Dukmasov, who totally agreed with the conclusions of the Maslakovets Commission, not only argued, as was shown above, that the training of Cossacks in the stanitsas had long become useless and even harmful but noted that most of the young dragoons who joined the units totally unprepared in October turned into perfectly prepared cavaliers in the ranks in summer A. I. Domontovich, on the contrary, was wary that abolishing the preparation grade would "simply obliterate the smoldering embers of the Cossack spirit", and, therefore, given that "a child develops a passion for what his father does", it was not advisable to put off the start of the Cossacks' military training until they turned 21, when the father's influence on the child in that respect was no longer as powerful as before ${ }^{77}$. Of interest is the view of Commander of the Moscow Military District Grand Duke Sergei Aleksandrovich, who suggested exercising care in implementing any major changes in the education of Cossacks, warning that "taking a wrong course in the matter could have highly undesirable consequences and considerably weaken the Cossacks' military morale"78. That being said, he too regarded as imperative the need to enhance shooting skills and "exercise stricter control over the training of young Cossacks" 79 . Yet these differences of opinion among the various battle commanders of the Russian army are not a major concern. The bottom line is that on the eve of the $20^{\text {th }}$ century all of them recognized that the then-existing system of training for Don Cossacks in the stanitsas was totally ineffective and insisted that it be transformed.

\section{Conclusion}

By the beginning of the $20^{\text {th }}$ century, the Don Cossacks' system of traditions related to military training was an artificial and relatively recent construct. The region's historically and naturally evolved martial games for young Cossacks began to die out no later than the early $19^{\text {th }}$ century, with I.S. Ulyanov and I.I. Krasnov, born at the beginning of the $19^{\text {th }}$ century, appearing not to have witnessed them. This, however, does not signify that the region's military traditions had perished entirely in the stanitsas - as far back as the 1860s did the Cossacks stage horseback riding and shooting contests during the week of Maslenitsa. It is just that these "martial game" contests were hardly considered of much value. Nonetheless, the extant elements of traditional military education became the basis for the launch of a system of proper, official education for young Cossacks in the 1860s - which would be regarded as quite effective by many, including D. A. Milyutin and the very same I. I. Krasnov. However, unfortunately it was impossible to stop the process of extinction of military traditions in the Cossack milieu in the period between the 1860s and 1870s. According to A. I. Domontovich, P.G. Dukmasova, and N. A. Maslakovets, the further, the stronger properly regulated education came into collision with the Cossacks' real needs and traditions. As a consequence, by the 1890s "natural" martial games no longer played a substantial role in preparing the Cossacks for service, whilst official training had become

77 Ibid. L. 64.

78 Ibid. L. 32 ob.

${ }^{79}$ Ibid. L. 32. 
so ineffective that they had to retrain young Cossacks in the regiments. It came to the point that Don general P.G. Dukmasov and the members of the Maslakovets Commission who were from the Don stanitsas requested that the authorities provide joint training to the Cossacks and dragoons, i. e. to have draftees from the stanitsas undergo training in the regiments now, after being called up!

Accordingly, the image of the Cossack as a "dashing equestrian warrior" 80 , so typical in pre-revolutionary official historiography, must be perceived with caution, if not with skepticism. An analysis of the War Ministry's internal documentation indicates that in the second half of the 1890s nearly half of the draftees from the Don region were prepared for service poorly or unsatisfactorily altogether. One could encounter scores of Cossacks who not just were poor horseback riders but seemed to have "never ridden a horse before". Certain officers were unable to ride a horse simply due to their "phenomenal corpulence". That being said, the issue of many of the Don Cossacks unpreparedness for service arose no later than the 1860s, when it drew the attention of Alexander II. Certain contemporary historians trace the crisis of the Cossacks' system of military traditions even further back - to the 1820 s.

As regards the Cossacks' spontaneous martial games, these could be divided into two major groups, with the reservation that there are not so many credible descriptions out there of what these games were like during the period under examination. Only two authors, I.I. Krasnov and S. F. Nomikosov, describe large-scale group games that were most beneficial to military training, which involved forming two separate detachments (e. g., the "Cossacks" and "Turks") and staging a mock battle. However, as was shown above, S. F. Nomikosov's account has yet to be confirmed by other authors and appears somewhat embellished, while I. I. Krasnov describes an uncertain past altogether. Consequently, it may be stated with confidence that this kind of large-scale games were no longer organized in the first half of the $19^{\text {th }}$ century, while in the century's second half, even if they had been revived, they were staged quite rarely. At the same time, what seems quite plausible is that to older-generation Cossacks, like the above-mentioned I. I. Krasnov and I.S. Ul'yanov, it is these two-way battles that were real traditional Don Cossack martial games, whilst less significant contests, which technically dealt with the honing of military skills too, were regarded by them as ordinary, everyday games. This is the only way to explain their view of martial games in the Don region as having died out, whilst martial games in the second group were in use in the stanitsas at least up until the 1860s.

The second group is made up of martial games in which the Cossacks competed with each other individually in skills that are crucial for military service. This incorporates festive horseracing and fist fighting contests, mentioned by M.N. Kharuzin, and shooting and equestrian contests staged during the week of Maslenitsa, mentioned by N. I. Krasnov. However, with all the outward effectiveness of these games, their real benefit for military service was equivocal. For instance, horse races were usually won by stanitsa residents who could afford to buy a charger in advance, while fist fighting was not a distinct discipline with the Cossacks. Nonetheless, by the end of the $19^{\text {th }}$ century unfortunately only these games, not related in any way to the provision of proper training to the Cossacks by stanitsa instructors, remained in place. The Cossacks, generally, advocated keeping these games in place and developing them, acknowledging that while they could no longer pro-

${ }^{80}$ Krasnov P. N. Kartiny bylogo Tikhogo Dona. P. 521. 
duce a full-fledged warrior, they could still help obtain "pristine material" to be trained when in the combatant forces - draftees who did not know the fundamentals of combat horseback riding but at least were "firm in the saddle".

Lastly, it is also possible to single out a third group, which includes games that may once have had a military subtext to them but lost it with the passage of time. Among those mentioned above, the most glaring example of this type of activity is "walking with the flag", which, according to M.N. Kharuzin, eventually had turned into ordinary visits to houses in the area for the mere purpose of partying. The existence of games like this is eloquent testimony to the decline of the Cossacks' system of military traditions in the second half of the $19^{\text {th }}$ century.

When talking about the Cossacks' military traditions, it is customary to draw upon testimonies from various decades and even centuries. A good example is the writings of A. V. Iarovoi. In other cases, historians appeal exclusively to formal texts that idealize the Cossacks, as is the case with N. V. Ryzhkova. This way of doing it, however, distorts the reality and substitutes myths about the Cossacks' military traditions for the real history of them. Only serious work with the sources and an understanding of the fact that, in essence, much of the system of military traditions of late Don Cossackdom was an artificial construct of the second half of the $19^{\text {th }}$ century, intended to restore or to replace the half-forgotten military traditions of the $18^{\text {th }}$ century, can help us to obtain an answer to the question of what Don Cossackdom was like in actual fact.

\section{References}

Iarovoi A. V. Traditional war games of the Don Cossacks in the context of preserving historical memory. Voina $i$ voinskie traditsii $v$ kul'turakh narodov Iuga Rossii. VII Tokarevskie chteniia. Rostov-on-Don, Altair Publ., 2018, pp. 14-22. (In Russian)

Kashkarov A.P. Cossacks: traditions, customs, culture (a brief guide to the true Cossack). Rostov-on-Don, Phoenix Publ., 2015, 125 p. (In Russian)

Matveev O. V. From the historical and military-cultural heritage of the Cossacks of Kuban. Krasnodar, Ecoinvest Publ., 2011, 252 p. (In Russian)

Mininkov N. A., Mininkova L. V. The Cossack Region of Russia in the Characteristics of Russian Travelers of the Modern Era. Bylye Gody, 2019, vol. 54, iss. 4, pp. 1761-1771. (In Russian)

Peretyatko A. Y. "Look, the British and the French": a Little about the Don Literary Propaganda during the Crimean War. Propaganda in the World and Local Conflicts, 2018, no. 5 (2), pp.39-48.

Peretyatko A. Y. At the Origins of Don Military Propaganda: the Creative Activity of I.S. Ul'yanov at the Time of the Crimean War. Propaganda in the World and Local Conflicts, 2019, 6 (1), pp. 8-18.

Ryzhkova N. V. Don Cossacks in the wars of the early $20^{\text {th }}$ century. Moscow, Veche Publ., 2008, 448 p. (In Russian)

Volvenko A. A. D. A. Milyutin and Cossacks. Bylye Gody, 2016, vol. 40, iss. 2, pp. 398-411. (In Russian)

Volvenko A. A. Ivan Krasnov about "the Cossack nationality" and "the Don patriotism" (Based on Periodicals of the 1860s). Russkaia Starina, 2016, vol. 17, iss. 1, pp.33-40. (In Russian)

Zakharevich A. V., Skiba K. V. About the Don Cossacks, who served on the Kuban line in the 1790-1830's. Rossiiskaia gosudarstvennost'v sud'bakh narodov Kavkaza - IX. Piatigorsk, Pyatigorsk State University Press, 2016, pp.90-98. (In Russian)

Статья поступила в редакцию 27 февраля 2020 г. Рекомендована в печать 8 июня 2020 г. Received: February 27, 2020 Accepted: June 8, 2020 